\title{
Experimental Data on Dynamic Changes of Radio Pulses When They are Emitted by Piezoceramic Electromechanical Transducers
}

\author{
O.H. Leiko ${ }^{1, \star}$, A.V. Derepa ${ }^{2, \dagger}$, O.M. Pozdniakova ${ }^{2, \ddagger}$, O.V. Bogdanov ${ }^{1, \S}$ \\ ${ }^{1}$ National Technical University of Ukraine "Igor Sikorsky Kyiv Polytechnic Institute", 37 Peremohy Ave, \\ 03056 Kyiv, Ukraine \\ 2 The Central Scientific Research Institute of Armament and Military Equipment of the Armed Forces of Ukraine, \\ 28 Povitroflotsky Ave, 03049 Kyiv, Ukraine
}

(Received 01 June 2021; revised manuscript received 04 December 2021; published online 20 December 2021)

\begin{abstract}
The article discusses the issue of distortion of acoustic signals emitted by piezoelectric transducers in relation to electrical excitation signals. It has been shown experimentally that in acoustic locating systems, exciting electrical pulse signals differ significantly from the acoustic pulses emitted by them. The study was carried out on a cylindrical piezoceramic transducer. The reason for these differences is the presence of piezoceramic electromechanical transducers in radar systems. Their resonant oscillatory systems are formed by two circuits, electrical and mechanical, interconnected by an ideal electromechanical transformer. The physical properties of these contours differ significantly in their purposes and properties. The electrical circuit of the converter is involved only in the conversion of energy, and its mechanical circuit is involved both in the conversion of energy and in its formation in the environment. The main difference in the properties of the circuits is the significant inertia of the mechanical circuit as a mechanical resonant oscillatory system and the inertia of the medium loading it when sound is emitted. This explains the occurrence of transient processes during the formation of acoustic pulses and their absence during the formation of electrical pulses. The distortions of acoustic pulses caused by transient processes have been experimentally established. They consist of a smooth rise of the leading edge of the acoustic pulse and the decay of its rear front, as well as the appearance at the beginning and at the end of short, sharp "bursts" of acoustic pressure amplitudes. It is shown that the magnitude and nature of the manifestation of dynamic distortions of acoustic pulses depend on the ratio of frequencies of harmonic filling of electrical pulses and the frequency of mechanical resonance of a piezoceramic electromechanical transducer. Filling frequencies of $3.5,7$ and $10 \mathrm{kHz}$ were investigated, which correspond to frequencies below the mechanical resonance of the transducer, the resonance frequency, and frequencies above the mechanical resonance. It is concluded that it is necessary to assess the resolution of acoustic locating devices based on their acoustic pulses of radiation and reception.
\end{abstract}

Keywords: Acoustic pulses, Piezoceramic transducer, Experiment.

DOI: $10.21272 /$ jnep.13(6).06022

PACS number: 77.65.Dq

\section{INTRODUCTION}

Modern acoustic location systems for various purposes in most cases operate in pulse modes. This is also true for underwater acoustic systems $[1,2]$ and for solid state control systems. This is due to the need to provide them with such parameters of the systems as the resolution of range, angular coordinates, and speed of movement of the objects being located [1,2], the accuracy of determining the coordinates of objects $[1,3]$, reduction of the dead zone [3]. In this case, the emitted acoustic signal must satisfy a number of contradictory requirements, for example, to ensure the specified resolution capabilities, in terms of range and speed of the objects being located.

The relevance of solving the formulated tasks is determined by the increase in the parameters of the above technical indicators of the systems. However, on the way to the practical implementation of this relevance, a number of problematic issues arise.

Technically, the pulsed radiation mode of radar systems differs from the continuous mode by the emergence of a number of new physical factors. These include forms of electrical excitation impulses, pulse duration, the nature of the frequency filling, periodicity of impulse excitation.

In physical terms, acoustic location systems differ from radio engineering systems by the emergence of the need to convert one type of energy into others, namely, electrical energy into mechanical and acoustic, in the radiation mode, and vice versa - in the receiving mode. Since acoustic mechanical systems are formed from electromechanical energy converters, which are characterized by the properties of inertia and elasticity, their non-stationary excitation is the cause of transient processes when switching on/off pulses of electrical excitation of these converters. The resulting features in the formation of mechanical and acoustic fields of acoustic location systems during emission and reception of sound can lead to a significant deterioration in their output parameters estimated only by the parameters of electrical impulses of their excitation.

The analysis of published materials [4-16] indicates

\footnotetext{
*log40413-ames@1ll.kpi.ua

†derepaan@i.ua

‡olpozdnjakova@gmail.com

§oleksiib@gmail.com
} 
that in the design support for detecting distortions in the parameters of pulses of acoustic location systems, the greatest success was achieved in non-destructive testing [5-13]. This is due to the use of a simpler and more advanced numerical method for determining the parameters of pulses - the method of equivalent electromechanical circuits $[4,5]$. Using this method, the influence on the parameters of pulses during emission of sound energy into solids is determined by the design parameters of the transducer [6], the multilayer design of the transducer [7, 8], the electromechanical coupling coefficient of the piezoceramic parameters of the transducer [9], the shape of the transducer [10,11], correcting electric circuits [12] and the "emissionreception" system as a whole [13].

A completely different situation with the computational support for estimating the distortions of emitted acoustic pulses has developed in underwater acoustics during the operation of radar systems. And it is connected with the need to take into account the fine structure of the sound field formed by the location system in the aquatic environment. To do this, it is necessary to leave the method of equivalent electromechanical circuits and pass, when assessing the generated acoustic fields during their emission and reception, to the method of coupled fields in multiply connected regions. This method is based on the joint solution of a system of differential equations, which include the wave equation describing the propagation of sound waves in the media surrounding transducers of the location system, equations of electromechanical vibrations of system transducer structures and equations of state of piezoelectric ceramics in transducers. To date, such an approach has been considered for acoustic location systems with stationary excitation of their transducers [14-16]. The complexity and underdevelopment of methods for calculating the formation of mechanical and acoustic fields of such systems in pulsed modes of their operation leads to the need for an experimental assessment of these fields in the indicated modes of operation of location systems.

The aim of this work is to obtain and analyze experimental data on the dynamic changes in electrical impulses of excitation of piezoceramic electromechanical transducers when they are converted into acoustic impulses and the latter are emitted into the surrounding aquatic environment.

\section{ON THE PHYSICAL CHARACTERISTICS OF THE CONVERSION OF ELECTRICAL IMPULSES INTO ACOUSTIC IN PIEZOCERAMIC ELECTROMECHANICAL TRANSDUCERS IN THE MODES OF RADIATION AND RECEPTION}

Electromechanical transducers consist of two interconnected parts, electrical and mechanical, and are designed to perform two functions: the function of converting energy and the function of generating acoustic energy in the surrounding space. Each of these functions has its own physical characteristics. The peculiarity of the first function of piezoceramic electromechanical transducers is the presence of an interconnection between three physical fields electrical, mechanical, and acoustic, involved in the process of energy conversion [3, 14-16]. A feature of the second function of the transducer is the interaction of acoustic fields created by the elements of the transducer's structure in the process of forming its full acoustic field [14-16].



Fig. 1 - Multi-circuit equivalent electromechanical circuit of the converter in radiation mode 
It is the presence of an acoustic field in both processes that determines the appearance of the interaction and these processes themselves.

The most clearly described physical processes in electromechanical converters with the presence of piezoceramic media are demonstrated by multi-circuit equivalent electromechanical circuits of converters (see Fig. 1) [3-5].

In Fig. 1, the electrical part of the converter is represented by a single-circuit diagram, in which $U$ and $I$ are the voltage and excitation current of the transducer, $R_{e l}$ and $C_{0}$ are the dielectric loss resistance and electrical capacitance of its piezoelectric ceramics. The mechanical part of the converter is represented by a multi-circuit diagram $(i=1, \ldots, N)$, each contour of which describes natural mechanical vibrations on the $i$ th form $(i=1, \ldots, N)$ of its vibration, wherein each $i$-th mode of vibration has its own natural frequency and its circuit parameters: $\vartheta_{i}$ is the vibrational velocity, $m_{e k v} i$, $c_{e k v} i, r_{m l}, z_{s}$, are the equivalent weight, flexibility, resistance to mechanical losses and radiation transmittance, respectively, for this form of oscillation. The electrical and mechanical parts of the converter are connected to its own transformer with conventional electromechanical transformation coefficient $n_{i}(i=1$, $\ldots, N)$ corresponding only to this mode of vibration.

Even a simple analysis of the equivalent circuit of the converter makes it possible to assert that the physical processes, accompanying the passage of pulse signals in the electrical and mechanical parts of the converter, differ significantly from each other. Naturally, these differences should also be reflected in the parameters of electrical and acoustic pulses of excitation and radiation of the transducer.

In the process of energy conversion, the electrical part of the converter in real time, typical for sound processes, practically does not show inertial signs. At the same time, the mechanical part, which plays a role in the transformation of energy and its formation, has several features. When energy is converted, the mechanical oscillatory system of the transducer and the elastic medium adjacent to it, in which acoustic signals propagate, are characterized by certain inertial properties. When the energy converter is formed, the acoustic interaction between the elements of its structure, which is the result of the occurrence of a multiple process of radiation and re-reflection of sound waves, also affects the emitted acoustic pulses.

The described features are qualitatively manifested as follows. After the start of the action of the electrical pulse, mechanical oscillations of the converter appear with deceleration, which leads to deformation of the leading edge of the electric pulse. After the termination of the action of the electrical impulse, the mechanical oscillations of the transducer continue for a certain time and, therefore, the rear front of the electrical impulse also undergoes changes. In this case, mechanical vibrations in these time periods should be characterized by complexity and difference in shape in the interval between the beginning and the end of the action of the electrical impulse.

\section{EXPERIMENTAL STUDIES AND THEIR RESULTS}

The above qualitative differences in the laws of rise and fall of radiation pulses require experimental verification. Its purpose was to experimentally evaluate changes in the shape of two impulse signals - an electrical one that excites an electromechanical transducer and an acoustic one emitted by this transducer into the environment. Experimental evaluation was carried out in a muffled measuring hydroacoustic basin with dimensions $8 \times 4 \times 5 \mathrm{~m}^{3}$ equipped with special measuring equipment and devices (Fig. 2).

In the measuring pool 1 , in its center, on the same line and at some distance from one another $(\sim 3 \mathrm{~m})$, there are the tested piezoceramic cylindrical emitting transducer 2 (made of piezoelectric ceramics of composition $\mathrm{ZnTBPb}$-3) with a diameter of $140 \mathrm{~mm}$ and a height of $38 \mathrm{~mm}$ and the broadband measuring spherical hydrophone 5 with a diameter of $15 \mathrm{~mm}$. The inverter 2 (Fig. $2 \mathrm{~b}$ ) is connected to the output of the generator of rectangular pulses 3 through resistance $R$. The duration of these pulses $\tau$ is chosen so that $\tau \geq \tau_{0}$, where $\tau_{0}$ is the time constant of the mechanical

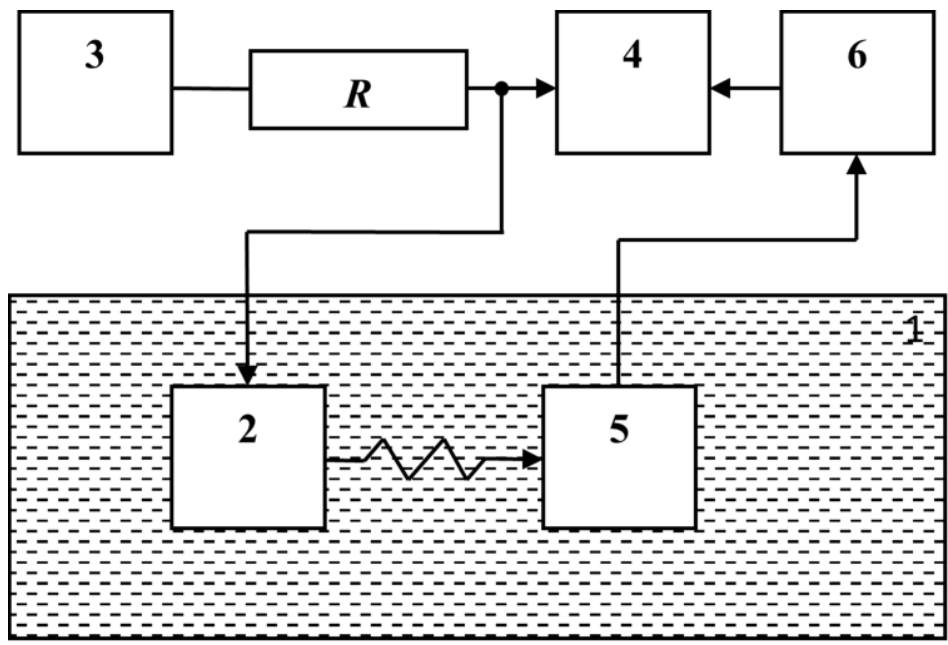

a

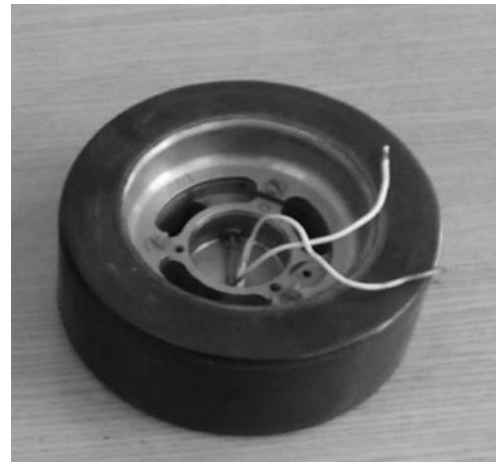

$\mathrm{b}$

Fig. 2 - Block diagram of the construction of a measuring stand (a) and a sample (b) of the measured transducer 
oscillatory system of the converter 2 in the zero mode of its oscillations. For this mode of vibration, the frequency of the mechanical resonance of the transducer 2 is $7 \mathrm{kHz}$. The electrical excitation pulses of the transducer 2 are isolated on the resistance $R$ and recorded by the indicator 4 . The synchronization of the indicator 4 is carried out by the generator 3 . The acoustic pulse emitted by the transducer 2 into the aqueous medium is received by the hydrophone 5 , amplified by the amplifier 6 , and fed to the indicator 4 .


a
During the experiment, the filling frequency of the electrical excitation pulse changed and took values below $(3.5 \mathrm{kHz})$, equal to $(7 \mathrm{kHz})$ and above $(10.5 \mathrm{kHz})$ the frequency of the mechanical resonance of the converter.

The hydroacoustic measurements were carried out in accordance with the requirements specified in hydroacoustics [15]. Their root-mean-square error was 0.08 with a confidence level of 0.95 .

The measurement results are shown in Fig. 3.
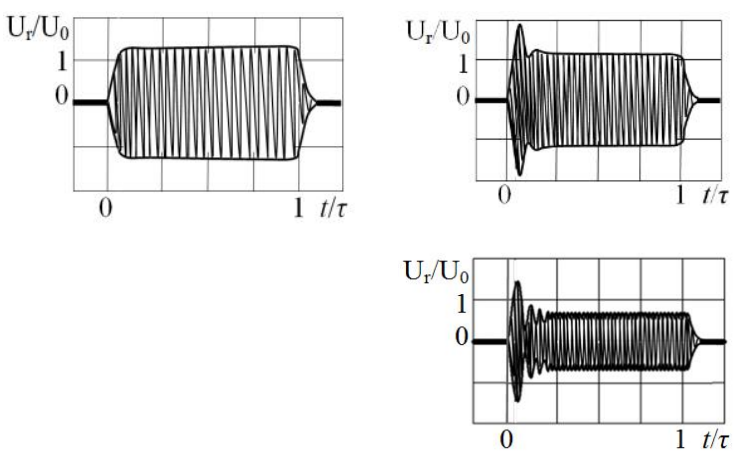

d

Fig. 3 - Forms of the exciting electric field (a) and the emitted pulse converter (b-d) of pulses with frequencies of harmonics filling them, lying below (b), equal to (c) and above (d) the frequency of the mechanical resonance of the converter in the zero mode: $U_{0}$ and $\tau$ are the amplitude and duration of the excitation pulse, $U_{\Gamma}$ is the hydrophone pulse amplitude

An analysis of the above results allows us to draw the following conclusions. First, we note that the shapes of electrical (a) and acoustic (b-d) impulses, as indicated in the qualitative analysis, differ significantly from each other. Electrical excitation pulses of the converter (Fig. 3a) do not show any signs of the appearance of transient processes in them. At the same time, the time diagrams of the acoustic pressure in the far zone of the transducer (Fig. 3b-d) illustrate typical distortions in the form of transient processes characteristic of pulses that have passed through mechanical resonance systems [2]. These distortions include a smooth rise of the leading edge of the pulse and a fall of the rear front. It should be noted that the duration of transient processes and their nature depend on the degree of remoteness of the frequencies of harmonic filling of pulses from the frequency of the mechanical resonance of the converter. In general, the durations of transient processes in acoustic pulses are close in magnitude in a wide range of frequencies of their filling. However, the nature of the manifestations of distortions significantly depends on the ratio between the pulse filling frequency and the frequency of the mechanical resonance of the converter. In the frequency range below (Fig. 3b) and above (Fig. 3d) the resonance of the transducer, at the beginning and at the end of the pulse, short sharp "bursts" of pressure amplitudes are observed. They can significantly negatively affect the efficiency of the sound emission from the transducer and its mechanical strength. In the region of resonant frequencies, distortions of the pulse shape are observed only in the form of a smooth rise and fall of the front.
The above experimental estimates of various effects of transient processes in electromechanical oscillatory systems of piezoceramic transducers with pulse signals in their electrical and mechanical circuits confirm the above possible physical reasons for their occurrence.

\section{CONCLUSIONS}

Dynamic changes in acoustic pulse signals emitted into the environment by an electromechanical piezoceramic hydroacoustic transducer were experimentally established in comparison with an electrical pulse exciting the transducer. It is shown that these changes are due to the emergence of transient processes in transducers as mechanical resonant systems. Typical distortions for emitted acoustic pulses are a smooth rise of the leading edge of the pulse and a fall of the rear front, as well as the appearance at the beginning and at the end of the pulse of short, sharp "bursts" of acoustic pressure amplitudes. It is established that the nature of the manifestation of the described distortions is determined by the difference in the frequencies of harmonic electrical oscillations of the pulse filling and the mechanical resonance of the transducer. The physical reasons for the appearance of distortion of emitted acoustic pulses are analyzed in comparison with exciting electrical pulses. The established dynamic changes in acoustic pulses in comparison with electrical ones must be considered when designing acoustic location devices, since their presence significantly worsens the output parameters of these devices estimated only by the parameters of electrical pulses. 


\section{REFERENCES}

1. Y.A. Koriakin, S.A. Smirnov, H.V. Yakovlev, Korabel'naya Gidroakusticheskaya Tekhnika: Sostoyaniye i Aktual'nyye Problemy [Ship Sonar Technology: State and Current Problems] (St.-Peterburg: Nauka: 2005).

2. V.T. Grinchenko, I.V. Vovk, V.T. Matsypura, Acoustic Wave Problems (Begell House: 2018).

3. S.I. Konovalov, A.G. Kuzmenko, Osobennosti Impul'snykh Rezhimov Raboty Elektroakusticheskikh P'yezoelektricheskikh Preobrazovateley [Features of Pulse Modes of Operation of Electro-acoustic Piezoelectric Transducers] (St.-Peterburg: Politekhnika: 2014).

4. V.T. Grinchenko, I.V. Vovk, V.T. Matsypura, Osnovy Akustiki [Basics of Acoustics] (Kyiv: Naukova dumka: 2007).

5. B.S. Aronov, J. Acoust. Soc. Am. 133 No 6, 3875 (2013).

6. S.I. Konovalov, A.H. Kuz'menko, Defektoskopiia No 6, 3 (2005).

7. M.A. Grigorev, A.V. Tolstikov, Y.N. Nevrotskaia, Akusticheskij Zhurnal 49 No 4, 489 (2003).
8. S.I. Konovalov, A.G. Kuzmenko, Defektoskopiia No 7, 39 (2005).

9. S.I. Konovalov, A.G. Kuz'menko, Akusticheskij Zhurnal $\mathbf{5 4}$ No 5, 744 (2008)

10. V.G. Savin, I.O. Morgun, Int. J. Appl. Mech. 43 No 2, 238 (2007).

11. S.I. Konovalov, A.G. Kuzmenko, J. Acoust. Soc. Am. 128 No 6, 3489 (2010).

12. S.I. Konovalov, A.G. Kuz'menko, J. Acoust. Soc. Am. 125 No 3, 1456 (2009).

13. S.I. Konovalov, A.G. Kuzmenko, Akusticheskij Zhurnal, 49 No 6, 852 (2003).

14. A.V. Derepa, A. Leiko, O. Pozdniakova, J. Nano- Electron. Phys. 9 No 3, 03017 (2017).

15. A. Leiko, A. Derepa, A. Rasstrygin, A. Kosiakovskyi, O. Kocharian, Y. Starovoit, Archive. Acoust. 44 No 1, 129 (2019).

16. A.V. Derepa, A.G. Leiko, O.N. Pozdniakova, Dev. Meth. Measur. 8 No 2,168 (2017).

\title{
Експериментальні дані про динамічні зміни радіоімпульсів при їх випромінюванні п'езокерамічними електромеханічними перетворювачами
}

\author{
О.Г. Лейко ${ }^{1}$ А.В. Дерепа ${ }^{2}$, О.М. Позднякова ${ }^{2}$, О.В. Богданов ${ }^{1}$ \\ ${ }^{1}$ Національний технічний університет Украйни "Кийвський політехнічний інститут імені Іеоря \\ Сікорського”, пр. Перемоги, 37, О3056 Київ, Украӥна \\ ${ }^{2}$ Центральний науково-дослідний інститут озброєння та військової техніки Збройних Сил Украӥни, \\ пр. Повітробблотський, 28, 03049 Київ, Україна
}

\begin{abstract}
У статті розглядається питання спотворень акустичних сигналів, які випромінюються п'єзоелектричними перетворювачами, по відношенню до електричних сигналів збудження. Експериментальним шляхом показано, що в акустичних локаційних системах збуджуючі електричні імпульсні сигнали істотно відрізняються від випромінюваних ними акустичних імпульсів. Дослідження проводилося на циліндричному п'езокерамічному перетворювачі. Причиною цих відмінностей е наявність в складі локаційних систем п'езокерамічних електромеханічних перетворювачів. Їх резонансні коливальні системи утворені двома контурами - електричним і механічним, пов'язаними між собою ідеальним електромеханічним трансформатором. Фізичні властивості цих контурів істотно розрізняються між собою за своїми призначеннями і властивостями. Електричний контур перетворювача бере участь тільки в перетворенні енергії, а його механічний контур - і в перетворенні енергії, і в $\dddot{1}$ формуванні в навколишньому середовищі. Основною відмінністю контурів у властивостях е значна інерційність механічного контуру, як механічної резонансної коливальної системи, і інерційність навантажувального ним середовища при випромінюванні звуку. Саме цим пояснюеться виникнення перехідних процесів при формуванні акустичних імпульсів і їх відсутність при формуванні електричних імпульсів. Експериментальним шляхом встановлено, що спотворення акустичних імпульсів обумовлені перехідними процесами. Вони полягають в плавному наростанні переднього фронту акустичного імпульсу і спаданні його заднього фронту, а також появі на початку і в кінці коротких, різких «сплесків» амплітуд акустичних тисків. Показано, що величина і характер прояву динамічних спотворень акустичних імпульсів залежать від співвідношення частот гармонійного заповнення електричних імпульсів і частоти механічного резонансу п'єзокерамічного електромеханічного перетворювача. Були досліджені частоти заповнення 3,5; 7 і 10 кГц, які відповідають частотам нижче механічного резонансу перетворювача, частоті резонансу і частотам вище механічного резонансу. Зроблено висновок про необхідність оцінки дозволяють здібностей акустичних локаційних пристроїв по їх акустичним імпульсам випромінювання і прийому.
\end{abstract}

Ключові слова: Акустичні імпульси, П'єзокерамічний перетворювач, Експеримент. 